\title{
NON-LINEAR MODELLING OF FERRO CASTING DUCTILE SHEAR KEY OF L-SHAPED CONCRETE BLOCKS WITH EPOXY JOINT USING MIDAS FEA
}

Putri Ardiyati

Universitas Indonesia, Depok, (Indonesia).

E-mail: Putri.Ardiyati@ui.ac.id ORCID: https://orcid.org/0000-0002-3025-8067

Nuraziz Handika

Universitas Indonesia, Depok, (Indonesia).

E-mail: n.handika@ui.ac.id ORCID: https://orcid.org/0000-0001-9165-9246

Heru Purnomo

Universitas Indonesia, Depok, (Indonesia).

E-mail: heru.purnomo@ui.ac.id ORCID: https://orcid.org/0000-0002-0570-2891

Recepción: 22/06/2021 Aceptación: 01/09/2021 Publicación: 14/09/2021

\section{Citación sugerida:}

Ardiyati, P., Handika, N., y Purnomo, H. (2021). Non-linear modelling of Ferro casting ductile shear key of L-Shaped concrete blocks with epoxy joint using Midas FEA. 3C Tecnología. Glosas de innovación aplicadas a la pyme, 10(3), $101-117$. https://doi.org/10.17993/3ctecno/2021.v10n3e39.101-117 


\section{ABSTRACT}

As cast iron with 10-15\% of graphite, Ferro Casting Ductile (FCD) Iron material has better mechanical properties than the ones from Grey Cast Iron. Moreover, it is also close to Carbon Steel's properties. Regarding this condition, FCD has the potential to be used as a shear key, specifically, as a joint of precast segmental concrete bridges. The objective of this paper is to study the mechanical behavior of FCD applied as shear key on a wet precast joint using epoxy. To do so, three-dimensional non-linear numerical modeling using Midas FEA was conducted on two L-shaped concrete blocks connected by a couple of FCD shear key representing precast concrete segmental bridge system. Between these two L-shaped blocks of concrete, epoxy adhesive was ap-plied. Both concrete blocks and FCD shear keys with 50\% scale of original geometries were used. The constitutive behavior of each material was obtained from previous test results and literatures. Loading applications were performed in two directions, vertical load to represent load from deck bridge and horizontal load to represent prestressing force. Load bearing capacity of FCD shear keys increases along with the increase of horizontal load. Non-linear analysis results show discrepancy comparing to the exper-imental ones, with a deviation reaches more than 7\%.

\section{KEYWORDS}

Ferro Casting Ductile, Male and Female Shear Keys, Force-Displacement Relations, Numerical Simulation. 


\section{INTRODUCTION}

Shear keys are prominently used in the joints of precast segmental concrete bridges. Prior to the use of metal shear keys, concrete shear keys have been used nowadays. The ultimate strength at the joint of precast concrete girders depends on the behav-ior of the material of joints between segments. The behavior of shear key joints, whether using concrete or metal as their primary material, has been a subject of several experimental studies in the past.

One of the studies is an experimental work by Zhou, Mickleborough and Li (2005). They studied the behavior of shear strength of joints in precast concrete segmental bridges. Several type of concrete shear keys such as flat shear keys, multiple shear keys, with and without epoxy have been ana-lyzed experimentally to investigate the shear capacity of each key in different kinds of joints. From this study, it is found that the shear strength of the joints increases with an increase in confining stress. Moreover, their experimental study stated that dry joints had an ultimate strength of approximately $20-40 \%$ less than epoxied joints.

Yuan et al. (2019) studied the shear behavior of epoxy resin joints with plain concrete shear keys, reinforced shear keys, internal post-tensioned tendon shear keys and concrete shear keys with inclined design. Following the experimental study that has been conducted by Yuan et al. (2019), several results found that reinforced shear keys and internal post-tensioned tendon shear keys with epoxy resin joints generates a superior performance in ductility behavior than any other type of shear keys test-ed in the experiment.

A series of tests resulted in a different epoxy resin joint failure mode for each design parameters. Epoxy joint with plain concrete shear keys exhibited typical shear off along the key base, reinforced shear keys demonstrated concrete covers crushed off over the reinforcing bar, meanwhile internal post-tensioned shear keys revealed cracks propagated deeply into the male and female specimens. The Japanese standard (Japan Society of Civil Engineering, 2007) recommends the use of FGD (ferro casting ductile) metal 
with grade 450 as a material for FCD shear keys. The Japa-nese standard's recommendation was verified by Purnomo et al. (2017) in their ex-periment.

Purnomo et al. (2017) found that shear keys with grade 450 have higher shear strength with the smallest displacement than any other FCD metal with grade range from 265-274 MPa (Compression yield stress). Purnomo et al. (2018) have conducted experiments with specific geometry shear key and different geometry shear keys. The geometry shear key used in this paper is also one of the types of shear keys which has been used by Purnomo and others in previous experiments. The methodology of the nonlinear models closely resembles the methodology in Purnomo and others' experimental study.

In this numerical study, non-linear analysis is performed by using two L-shaped concrete blocks representing precast concrete segmental bridge system. These two blocks are connected by male shear key in top of concrete blocks and female shear keys in bottom of concrete blocks. One layer of epoxy with thickness $1 \mathrm{~mm}$ is ap-plied between concrete blocks as representative of epoxy connection type in joint of concrete blocks. Pinned support is placed at the bottom of concrete blocks as its boundary condition. Afterwards, increment vertical load is mounted at top of upper concrete block to represent load which occur on top joint segmental concrete gird-ers. The horizontal load is applied at left of upper concrete blocks as representative of prestress force. The constitutive law applied for the nonmetal materials are the Total Strain Crack Model (T-S Crack Model).

\section{METHODOLOGY}

\subsection{NON-LINEAR APPROACH}

The non-linear analysis is made to simulate similar experimental test setup in pre-vious studies (Purnomo et al., 2017; 2018). The configuration of the test setup of precast concrete girder uses two concrete blocks as shown in Figure 1. The two con-crete block itself are set in a test frame which is equipped with two hydraulic pumps. One of the two hydraulic pumps is placed above the concrete blocks with 
vertical orientation to represent the incremental load which compresses the concrete block. Another one is placed in the center, beside the concrete block, with horizontal orien-tation to represent the equivalent prestress force. Four digital gauges are located uniformly in the vertical direction to record the vertical displacements in front and at the back of the concrete block. The correlation between the load and displace-ment is obtained from the recording of the load cell placed above the concrete block to represent incremental load and from the average of result from the four digital gauges to represent displacement.

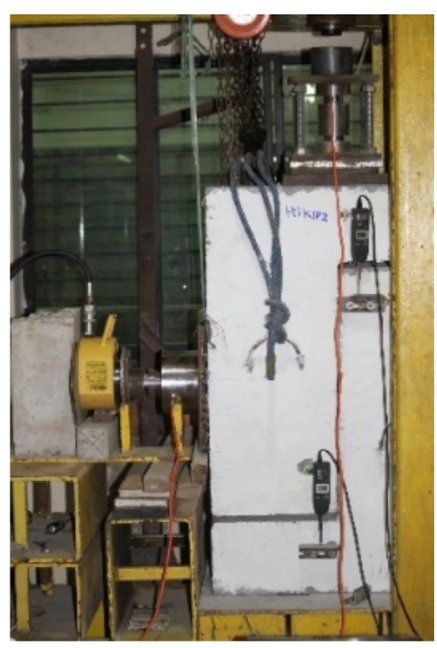

Figure 1. Laboratory Test Set-Up.

Source: own elaboration.

\subsection{SHEAR KEY GEOMETRY AND MATERIAL PROPERTIES}

The male and female shear keys are made of Ferro casting ductile with material grade of FCD 450. The concrete blocks are made of reinforced concrete with a 28-days compressive strength of $41.2 \mathrm{MPa}$, which is representative of the confined compressive strength of precast concrete girders. 
The geometry of the shear keys modeled in Midas FEA is presented in Figure 2. The male shear key is described in blue color. On the right side of Figure 2. is the female part of the shear key joint.

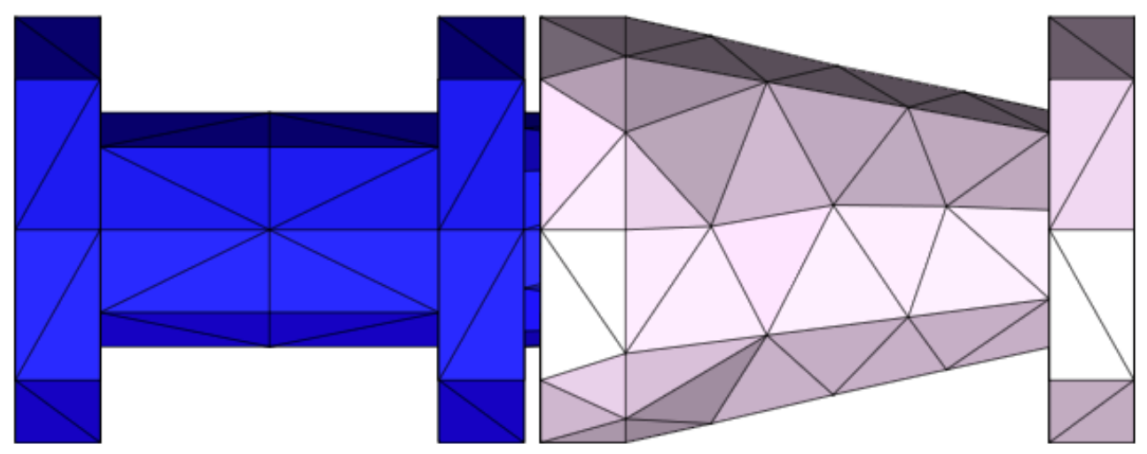

Figure 2. Geometry of the Male and Female Shear Keys (K1) in Midas FEA.

Source: own elaboration.

The dimensions of the concrete blocks and shear keys used in the test are shown in Figure 3. The numerical analysis uses a model of concrete blocks and shear keys with fifty percent downscaling in geometry. The geometry of the concrete blocks and shear keys are modeled using Autodesk inventor separately. The joint, made of ferro casting ductile shear keys, are located at the vertical midpoint of the upper concrete block and are casted into the female shear keys and bottom concrete block. The upper concrete block is mounted $10 \mathrm{~mm}$ higher than bottom concrete block. The vertical gap in between the concrete blocks is filled with epoxy joint with a thickness of $1 \mathrm{~mm}$.

Corresponding to the experimental study, vertical loads are applied as incremental load while the horizontal load needs to be maintained as linear load throughout the duration of the experiment. Due to limitations in the loading application setting in Midas FEA, the program cannot distinguish the two loads with different step of loading. 
Two numerical models are created in Midas FEA. The first model is a linear analy-sis model with only horizontal load is applied. This first model is used to identify the effects of horizontal load, which represents the prestressing force on the concrete block. The horizontal load is modeled in a linear model where its shear stress is ex-tracted and applied as additional shear stresses of the epoxy joint and concrete. The second model is a non-linear analysis model with incremental vertical displace-ments. The nonlinear model considers the additional shear stress from the first model which is applied to shear stress of epoxy joint and concrete.

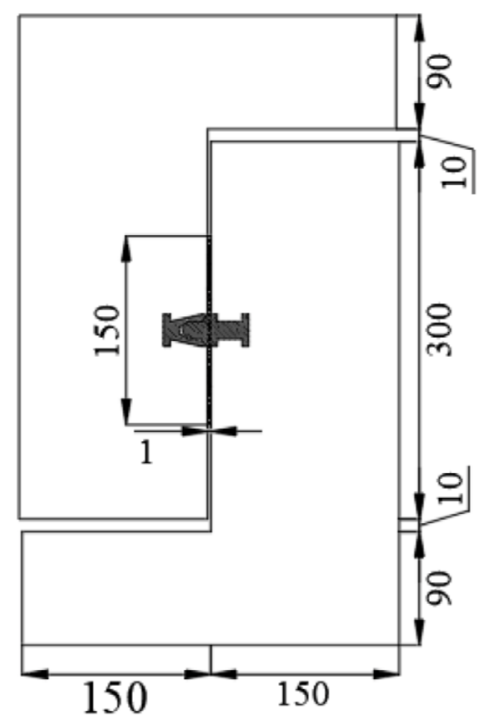

(a)

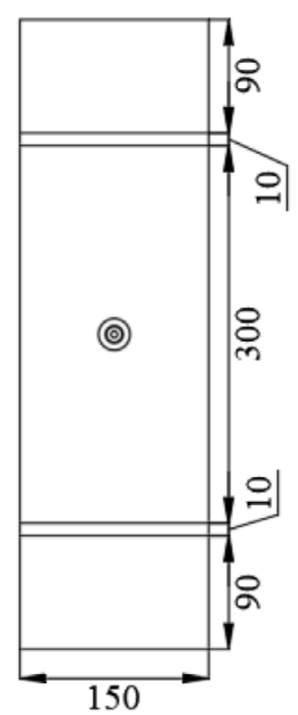

(b)

Figure 3. Dimensions of the Concrete and Shear Key Models. (a) Front view, (b) Cross Section View.

Source: own elaboration.

The engineering data of each of the materials in the joint precast concrete girders have been measured in the laboratory. The compressive stress-strain relationship of concrete obtained from cylindrical compressive strength test are acquired from the internal data of Structural and Material Laboratory 
of Universitas Indonesia ("Ma-terials Test Result Internal Data of Structural Laboratory at Universitas Indone-sia", 2020). The tensile strength of concrete model uses the formula obtained from $\mathrm{Hu}$, Lin and Jan (2004). In addition, the shear strength of concrete and the com-pressive, tensile and shear strength of epoxy are obtained from the internal data of Structural and Material Laboratory of Universitas Indonesia ("Materials Test Re-sult Internal Data of Structural Laboratory at Universitas Indonesia", 2020). The compressive and tensile stress-strain relationship of ferro casting ductile are also obtained from the laboratory. The stress -strain relation for FCD Material of each behavior is shown in Figure 4. The Poisson's ratio of concrete, ferro casting ductile and epoxy use the values $0.2,0.28$, and 0.35 , respectively.

The constitutive law for nonmetal material of numerical models uses Total Strain Crack model which is provided by Midas FEA. Meanwhile, failure behavior of each material uses different constitutive law. The maximum shear strength of the joint is measured by either the tensile failure of the concrete or the yielding of the shear keys. The epoxy joint can increase the shear capacity of the joint if applied with a proper thickness. The tensile failure of the concrete is assumed to be the maximum principal stress or Rankine's theory (Boresi \& Schimdt, 2003). Rankine's theory is assumed to occur when the maximum principal stress at any point reaches a value equal to the tensile stress of a simple tension specimen at failure. Correspondingly, the tensile failure at the upper concrete block occurs when the maximum principal stress reaches the tensile strength of concrete. Meanwhile, the failure criterion of ferro casting ductile shear key use the Von Mises criterion. Based on the Von Mises criterion, the yielding of the shear key occurs when the equivalent stress of a mate-rial under load is equal or greater to its yield limit (Boresi \& Schimdt, 2003). 


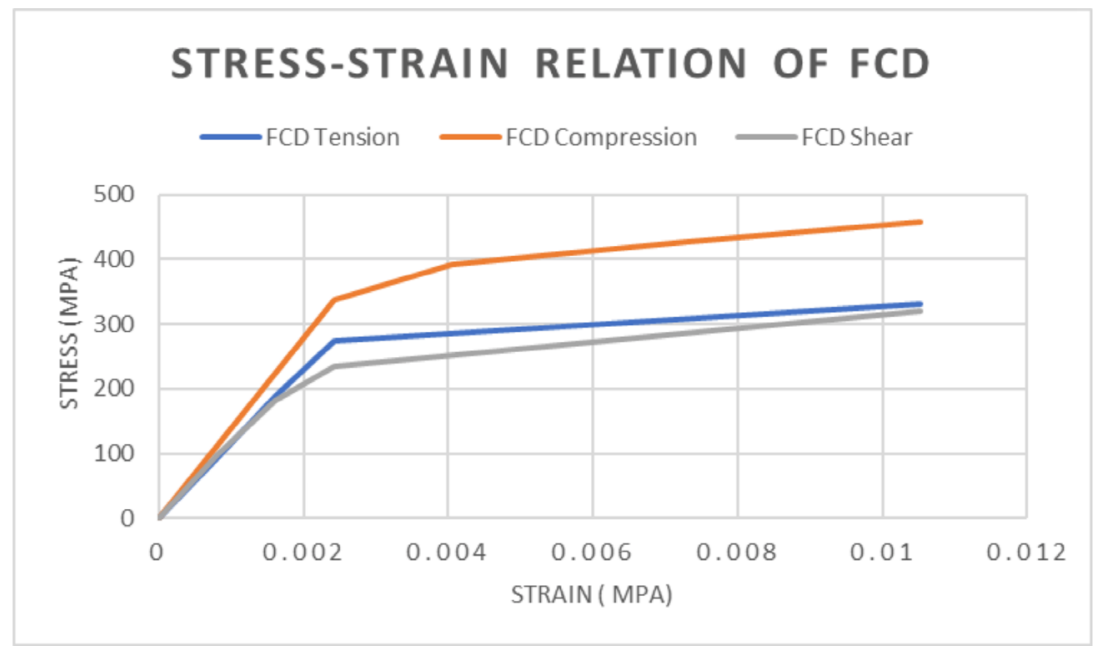

Figure 4. Stress-Strain Relationship for FCD Material.

Source: own elaboration.

In the following Table 1, stress representing prestress applied on the system as hori-zontal load is presented. Two different horizontal forces were used to examine and to find the adequate configuration of shear key and concrete block which produces the maximum shear capacity. These values are applied in the 1st numerical model-ling.

Table 1. FEA Analysis Variation.

\begin{tabular}{|c|c|}
\hline Variation & Initial Stress $(\mathbf{M P a})$ \\
\hline K1P3 & 0.345 \\
\hline K1P6 & 0.69 \\
\hline
\end{tabular}

Source: own elaboration.

The finite element model uses three-dimensional simulation in Midas FEA. Solid element with Total strain crack mode was used as the consecutive model of three primary materials. Contact between the concrete-shear key and the epoxy was de-fined as rigid contact with symmetric condition. Rigid contact 
is considered to be the contact between the shear key and concrete. Pinned boundary condition for the transversal axis is applied to the base of bottom concrete block. The upper concrete block was set free with no boundaries. Vertical displacements were applied above the upper concrete block. The vertical displacements are assigned in a 150x150 mm2 area incrementally. The horizontal load area is located on the left side of the upper concrete block. Two models of numerical analysis are schematically shown in Figure 5.
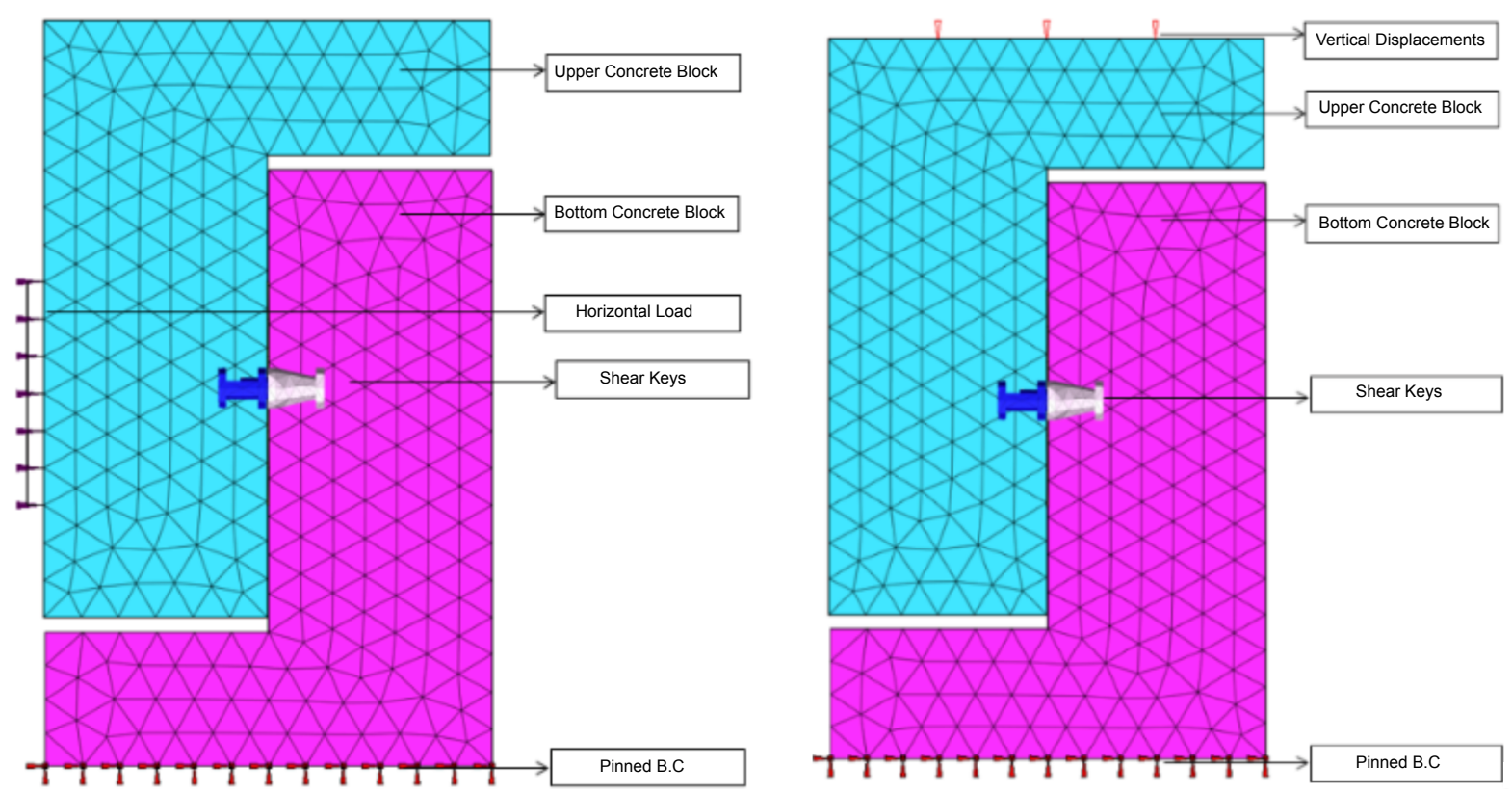

Figure 5. Linear and Non-Linear Models on Midas FEA. (a) 1st Model for Linear Analysis with Horizontal Load, (b) 2nd Model for Non-Linear Analysis with Vertical Load.

Source: own elaboration. 


\section{RESULTS}

\subsection{MAXIMUM LOAD CAPACITY OF JOINTS}

\begin{tabular}{|c|c|}
\hline K1P3 - Female Shear Keys & K1P6 - Female Shear Keys \\
\hline 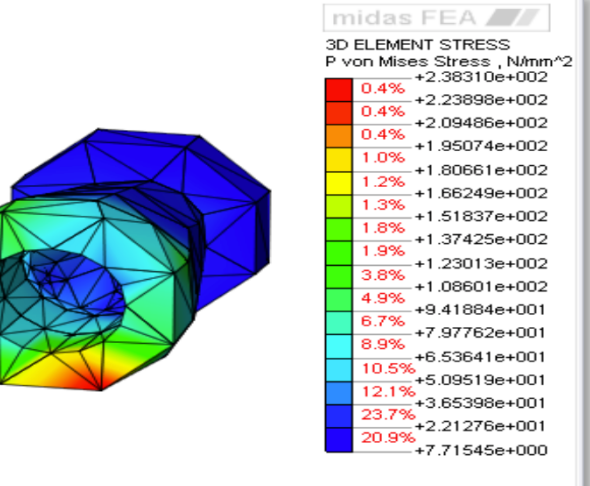 & 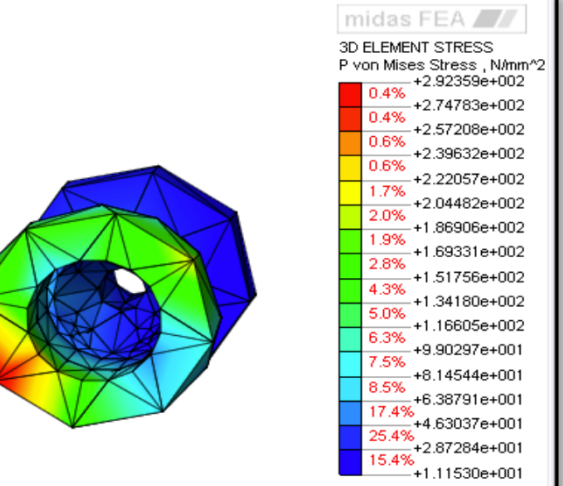 \\
\hline
\end{tabular}

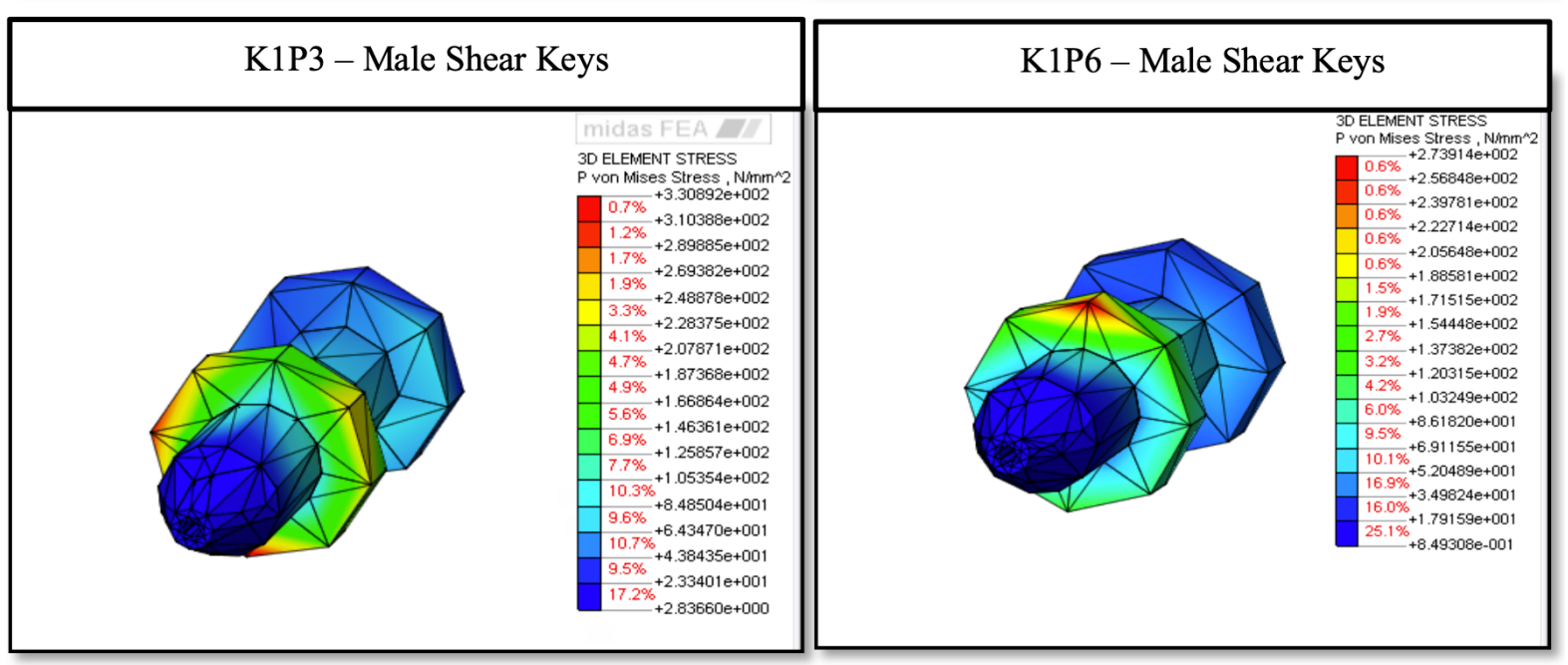

Figure 6. Von Mises Stress Contour in Male (Upper) and Female (Bottom) Shear Keys.

Source: own elaboration. 
Figure 6 displays the contour of Von Mises stress of each shear key with different initial stresses prior to reaching its maximum vertical load. Following the displayed contour of Von Mises stress, it can be seen that the male shear keys in every initial stress condition demonstrate the highest concentration of stress at the outer ring of the shear key. The highest concentration of stress of the female shear keys follows the male shear keys. The highest Von Mises stress of shear key is generated by vari-ation K1P3 with 331 MPa and K1P6's Von Mises Stress is 274, Meanwhile Female shear key of K1P6 exhibit greater stress than K1P3's Female shear key. The max-imum value of Von Mises Stress for each model exceeded the yield stress of ferro casting ductile shear key. The comparation of stress- strain relationship between two models is shown in below Figure 7. Based in graphic in Figure 7 maximum loads occurred in K1P6 greater than K1P3. The deviation between two models maximum load reach 37\%.

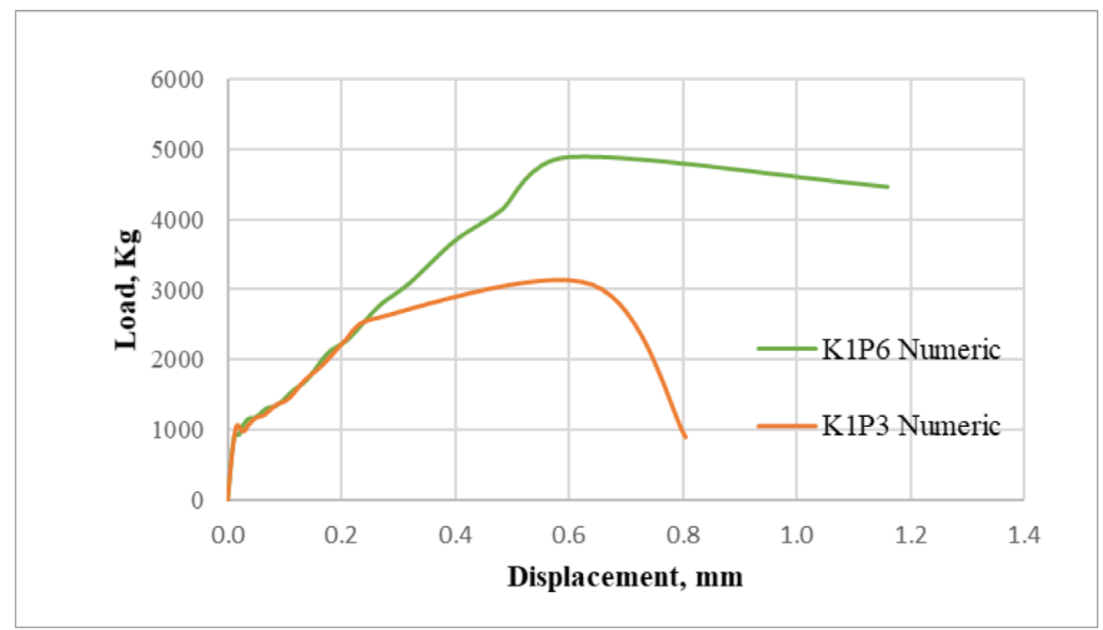

Figure 7. Load-Displacements Relationship of Shear Keys.

Source: own elaboration.

In Figure 7, K1P3 exhibit the lowest maximum vertical load which can be received by the concrete block. K1P6 exhibit ductile behaviour while K1P3 demonstrated brittle behaviour after reaching its maximum value, the graphic shows the load plunges after reaching the maximum load. In K1P6, the loads are decreasing after reaching its maximum value with displacement almost twice the displacement 
of maximum value. In accordance with these results, horizontal forces can affect the joint system. The maximum load demonstrates better value along with the in-creased horizontal force.

\subsection{COMPARISON BETWEEN EXPERIMENT RESULTS AND NUMERICAL ANALYSIS}

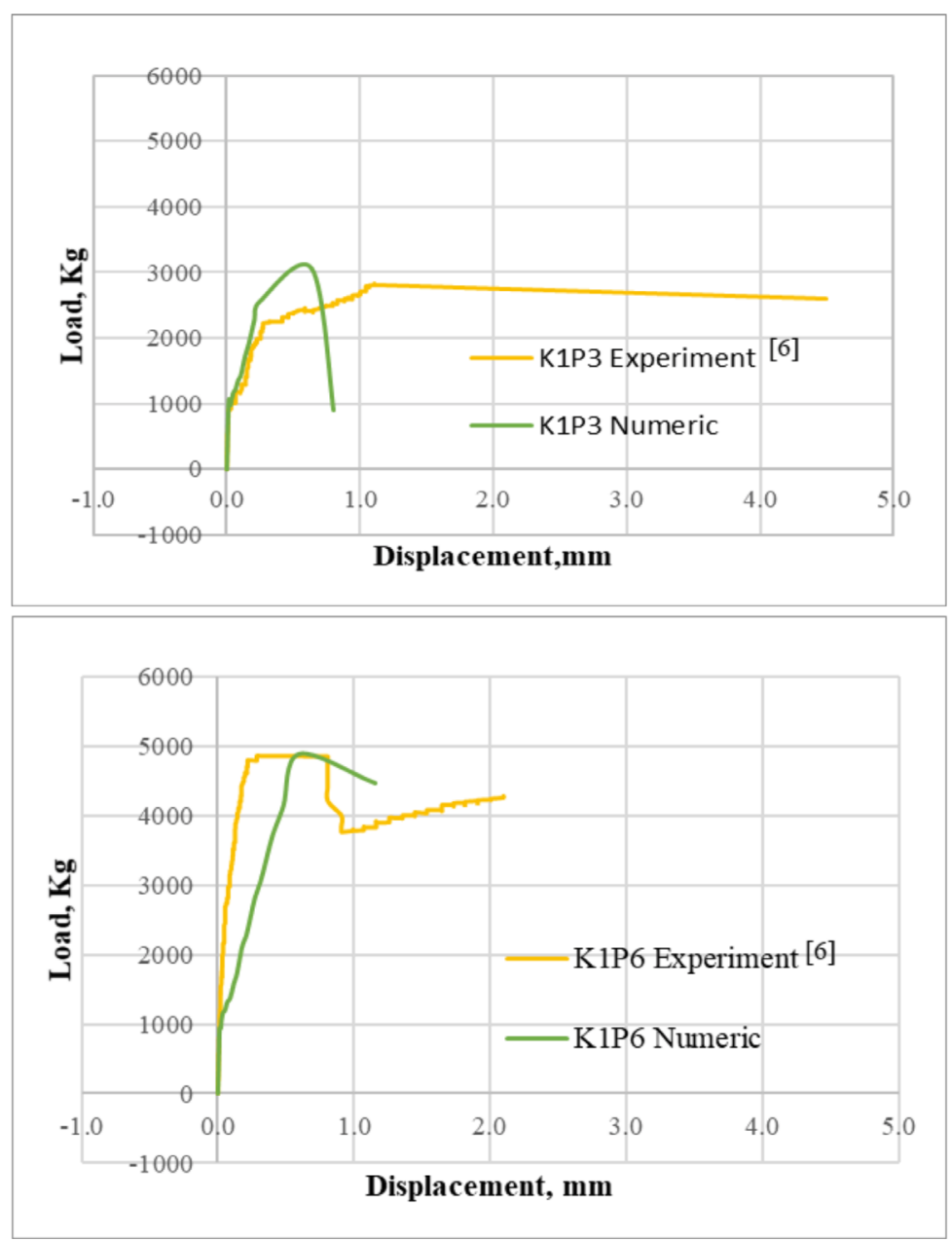

Figure 8. Comparison of Load-Displacement Relationship between Experiment Results and Nu-merical Analysis.

Source: own elaboration. 
Referring to Figure 8, comparing the graphic of load-displacement relation from experiment results and numerical analysis, the results are very disparate. For both models, failure occur due to brittleness. Therefore, the loads drop after reaching their maximum value. The different results between the experimental results and numerical analysis are due to several occasions that happened during the experiment. For example, an equal application of epoxy thickness between the concrete blocks is quite hard to achieve in experiment. Meanwhile, in the numerical model, thickness of epoxy can be arranged equally. The percentage value of deviation for each model are shown in Table 2. The minimum deviation occurs in the K1P6 model.

Table 2. Comparison of Results between Experiment and Numerical Analysis.

\begin{tabular}{|c|c|c|l|l|l|l|}
\hline \multirow{2}{*}{ Variation } & \multicolumn{2}{|l|}{ Max Displacement $(\mathrm{mm})$} & Deviation & \multicolumn{2}{l|}{ Max Force (Kg) } & \multicolumn{2}{l|}{ Deviation } \\
\cline { 2 - 7 } & Experiment & Numeric & $(\%)$ & Experiment & Numeric & $(\%)$ \\
\hline K1P3 & 1.11 & 0.64 & $42 \%$ & 2830 & 3066 & $8 \%$ \\
\hline K1P6 & 0.29 & 0.60 & $111 \%$ & 4870 & 4883 & $0 \%$ \\
\hline
\end{tabular}

Source: own elaboration.

\section{CONCLUSIONS}

Based on the numerical modelling of shear key and precast concrete block joint, it can be concluded that the maximum load capacity of the joint system occurs ac-cordingly with the increase of horizontal force. Following the contour of Von Mises stress, it can be seen that the highest stress is localized at the counter part of female shear keys of model K1P6. The results of experiment and numerical studies show different results due to limitation of application on experiments study and limita-tions of numerical study program. The load vs displacement curves obtain from numerical study are compared with the result of the experimental study. The choice of tensile stress-strain model for the concrete in the TS Crack Model affect the maximum load obtained by the numerical simulation. The experimental and nu-merical curves matched sufficiently up to before the rupture of epoxy layer, to be precise at the elastic linier region. Once it behaves non-linearly, passing $1000 \mathrm{~kg}$ of loading application, only K1P3 sample 
could exhibit close mechanical behavior to the experimental results. Furthermore, in case of K1P3, passing $2200 \mathrm{~kg}$ of loading application, the result of experiments and simulations are very different. It seems the damage in the system concrete blocks and shear key occurred largely. In the future works, the modelling can be improved, such as consideration of damage con-dition after the post peak of loading application.

\section{ACKNOWLEDGEMENTS}

We gratefully thank for Midas FEA to supporting this numerical study.

\section{REFERENCES}

Boresi, A. P., \& Schimdt, R. J. (2003). Advanced Mechanics of Materials (6th ed.). John Wiley \& Sons, Inc.

Hu, H.-T., Lin, F.-M., \& Jan, Y.-Y. (2004). Nonlinear Finite Element Analysis of Reinforced Concrete Beams Strengthened by Fiber-Reinforced Plastics. Composite Structures, 63(3-4), 271-281. https:// doi.org/10.1016/S0263-8223(03)00174-0

Japan Society of Givil Engineering. (2007). Standard Specifications for Concrete Structures "De-sign". JSGE Guidelines for Concrete No. 15. https://www.jsce-int.org/system/files/JGG15_Standard_ Specifications_Design_1.0.pdf

Materials Test Result Internal Data of Structural Laboratory at Universitas Indonesia. (2020). https://www.ui.ac. $\mathrm{id} / \mathrm{en} /$

Purnomo, H., Nursani, R., Mentari, S., Rahim, S. A., \& Tjahjono, E. (2017). Numerical Evaluation of the Shear Behaviour of a Metal Shear Key Used in Joining Precast Concrete Seg-mental Bridge Girders without Epoxy. International Journal of Technology, 8(6). https://ijtech.eng.ui.ac.id/ article/view/711 
Purnomo, H., Orientilize, M., Nursani, R., \& Hardjanto, F. (2018). Numerical Modelling and Simulation of Ferro Casting Ductile Shear Keys for Precast Concrete Girders. In ICCMS 2018: Proceedings of the 10th International Conference on Computer Modeling and Simu-lation, pp. 253-257. https:// doi.org/10.1145/3177457.3177479

Yuan, A., Yang, G., Wang, J., Chen, L., \& Lu, R. (2019). Shear Behaviour of Epoxy Resin Joints in Precast Concrete Segmental Bridges. Fournal of Bridge Engineering, 24(4). https://ascelibrary.org/ doi/abs/10.1061/\%28ASCE\%29BE.1943-5592.0001362

Zhou, X., Mickleborough, N. C., \& Li, Z. (2005). Shear Strength of Joints in Precast Concrete Segmental Bridges. ACI Structural fournal, 102(1), 3-11. https://www.researchgate.net/ publication/285773797_Shear_strength_of_joints_in_precast_concrete_segmental_bridges 
